\title{
The intellectual structure and substance of the knowledge utilization field: A longitudinal author co-citation analysis, 1945 to 2004
}

\author{
Carole A Estabrooks*1, Linda Derksen ${ }^{2}$, Connie Winther ${ }^{3}$, John N Lavis ${ }^{4}$, \\ Shannon D Scott ${ }^{5}$, Lars Wallin ${ }^{6}$ and Joanne Profetto-McGrath ${ }^{7}$
}

\begin{abstract}
Address: ${ }^{1}$ Faculty of Nursing, Third Floor Clinical Sciences Building, University of Alberta, Edmonton, Alberta, Canada, ${ }^{2}$ Department of Sociology, Vancouver Island University, Nanaimo, British Columbia, Canada, ${ }^{3}$ Department of Pediatrics, Faculty of Medicine, University of Alberta, Edmonton, Alberta, Canada, ${ }^{4}$ Department of Clinical Epidemiology and Biostatistics and Department of Political Science, McMaster University, Hamilton, Ontario, Canada, ${ }^{5}$ Faculty of Nursing, University of Alberta, Edmonton, Alberta, Canada, ${ }^{6}$ Department of Neurobiology, Care Sciences and Society, Division of Nursing, Karolinska Institute and Clinical Research Utilization (CRU), Karolinska University Hospital, Stockholm, Sweden and ${ }^{7}$ Faculty of Nursing, University of Alberta, Edmonton, Alberta, Canada
\end{abstract}

Email: Carole A Estabrooks* - carole.estabrooks@ualberta.ca; Linda Derksen - linda.derksen@viu.ca; Connie Winther - connie.winther@ualberta.ca; John N Lavis - lavisj@mcmaster.ca; Shannon D Scott - shannon.scott@ualberta.ca; Lars Wallin - lars.wallin@karolinska.se; Joanne Profetto-McGrath - joanne.profetto-mcgrath@ualberta.ca

* Corresponding author

Published: 13 November 2008

Implementation Science 2008, 3:49 doi:10.1/86/1748-5908-3-49
Received: 19 December 2007

Accepted: 13 November 2008

This article is available from: http://www.implementationscience.com/content/3/1/49

(c) 2008 Estabrooks et al; licensee BioMed Central Ltd.

This is an Open Access article distributed under the terms of the Creative Commons Attribution License (http://creativecommons.org/licenses/by/2.0), which permits unrestricted use, distribution, and reproduction in any medium, provided the original work is properly cited.

\begin{abstract}
Background: It has been argued that science and society are in the midst of a far-reaching renegotiation of the social contract between science and society, with society becoming a far more active partner in the creation of knowledge. On the one hand, new forms of knowledge production are emerging, and on the other, both science and society are experiencing a rapid acceleration in new forms of knowledge utilization. Concomitantly since the Second World War, the science underpinning the knowledge utilization field has had exponential growth. Few in-depth examinations of this field exist, and no comprehensive analyses have used bibliometric methods.

Methods: Using bibliometric analysis, specifically first author co-citation analysis, our group undertook a domain analysis of the knowledge utilization field, tracing its historical development between 1945 and 2004. Our purposes were to map the historical development of knowledge utilization as a field, and to identify the changing intellectual structure of its scientific domains. We analyzed more than 5,000 articles using citation data drawn from the Web of Science ${ }^{\circledR}$. Search terms were combinations of knowledge, research, evidence, guidelines, ideas, science, innovation, technology, information theory and use, utilization, and uptake.

Results: We provide an overview of the intellectual structure and how it changed over six decades. The field does not become large enough to represent with a co-citation map until the mid1960s. Our findings demonstrate vigorous growth from the mid-1960s through 2004, as well as the emergence of specialized domains reflecting distinct collectives of intellectual activity and thought. Until the mid-1980s, the major domains were focused on innovation diffusion, technology transfer, and knowledge utilization. Beginning slowly in the mid-1980s and then growing rapidly, a fourth scientific domain, evidence-based medicine, emerged. The field is dominated in all decades by one individual, Everett Rogers, and by one paradigm, innovation diffusion.
\end{abstract}




\begin{abstract}
Conclusion: We conclude that the received view that social science disciplines are in a state where no accepted set of principles or theories guide research (i.e., that they are pre-paradigmatic) could not be supported for this field. Second, we document the emergence of a new domain within the knowledge utilization field, evidence-based medicine. Third, we conclude that Everett Rogers was the dominant figure in the field and, until the emergence of evidence-based medicine, his representation of the general diffusion model was the dominant paradigm in the field.
\end{abstract}

\section{Background}

The use of knowledge (and science) for the betterment of society is an overarching theme in much of western thought. Knowledge plays such a central role in contemporary societies that they have become known as knowledge societies [1,2]. Many facets of contemporary societies depend increasingly on science and technology [2-4]. Science is not, however, separate from society, and developments in the scientific community are linked to societal changes [5]. How to put knowledge to use is a universal human problem. The problem of putting knowledge to use has been characterized in several ways - for example, as a theory-practice gap [6], as a failure of professionals to adopt evidence-based practices [7], as an inability to bring technological innovations to market [8], and as a lag between discovery and uptake $[9,10]$. Differences among the various characterizations often occur along disciplinary lines, and along differences in how knowledge is conceptualized, differences in context, and differences in the nature of the producers and users of the knowledge as well as the particular goals each holds within their context. In the health arena, the consequences of not using new knowledge are believed to be dire [11-14], and the agenda of knowledge use has been taken up with vigor at least among proponents of evidence-based decisionmaking or evidence informed policy processes.

The field of study in which scholars address these gaps and related issues of importance can be generally labeled knowledge utilization. Many variations in terminology exist, among them innovation diffusion, knowledge translation, research utilization, knowledge mobilization, and technology transfer. These variations commonly signal different groups of scholars and sometimes different disciplines. While these scholars are readily identifiable to those familiar with the field or one of its subfields despite calls for a discipline of knowledge utilization [1520], such a discipline has not to date emerged. Although Cottrill, Rogers, and Mills [21] conducted a modified cocitation analysis of 110 authors drawn from the early (1966 to 1972) diffusion of innovation and technology transfer literatures, we could locate no published attempts to map the structure of the scientific community grouped under the rubric of knowledge utilization across disciplines or to map its changes over time.

\section{Knowledge utilization as a field of study}

White, Wellman, and Nazer [22] make the case that objective maps of intellectual structure produced using author co-citation analysis (ACA) have a deep affinity with insiders' perceptions of the structure of their own fields. We held such an insider perception as we began, and that perception is reflected in the following brief overview of the knowledge utilization field and its most obvious subsets (domains). These domains (knowledge utilization, diffusion of innovation, technology transfer, evidence-based medicine or EBM) are, we argue, substantively similar on the basis that they all address the idea of solving social problems with knowledge. They differ along such dimensions as core problems of concern, knowledge used, audiences of relevance, and sometimes modes of transfer.

Rich has argued that the roots of the knowledge utilization field date back to the time of the ancient Greeks [23], although most scholars date it no further back than the earliest studies in innovation diffusion credited to the French sociologist Gabriel Tardé over a century ago [24]. Numerous literatures and traditions (some overlapping) are subsumed within the broad knowledge utilization domain. Some authors have conceptualized knowledge utilization as a broad domain over-arching all others $[25,26]$. We believe that there has been a strong thread that constitutes knowledge utilization proper whose scholars concern themselves with the relationship of knowledge (often in the form of scientific research) to policy $[17,23,27-35]$. The most often cited source from this broad overarching knowledge utilization field is Glaser, Abelson, and Garrison's encyclopedic review of the literature on the topic [36]. Backer described the evolution of the knowledge utilization field specifically [37]; Valente and Rogers [38] and Rogers [10] described evolution of the closely related field of innovation diffusion. Beal, Havelock and Rogers offered additional insights into the origins of the field of knowledge utilization, termed by them "knowledge generation, exchange, and utilization" (KGEU) [39]. Havelock argued that the parent discipline of KGEU was sociology, and acknowledged social and organizational psychology as important contributors. Rogers in this same volume clarified the importance of the agricultural extension model and its influence on the thinking of scholars in the field. 


\section{Diffusion of innovations as a field of study}

One of the most identifiable domains within a knowledge utilization framework, and until recently the most dominant, is diffusion of innovation. The history of the development of innovation diffusion as a research tradition is well-documented $[10,38,40]$. Rogers credited the Ryan and Gross classical agricultural study on hybrid corn as creating the template for classical diffusion theory for 40 years [41]. Rogers [10,42] identified nine diffusion research traditions: anthropology, early sociology, rural sociology (dominant until the 1960's), education, public health/medical sociology, communication, marketing, geography, general sociology, and a miscellaneous "other". Valente and Rogers used a Kuhnian framework for their analysis of the rise and fall of the diffusion paradigm among rural sociologists - arguing that the diffusion paradigm faded as a result of a paradigm shift. Although innovation diffusion theory is often described as Rogers' "Theory of Innovation Diffusion", it is more accurate to talk about Rogers' representation of innovation diffusion theory. Crane [40] and Valente and Rogers [38] show that the Ryan and Gross publication formulated the diffusion model. By the mid-1950s, a group of rural sociologists had filled in the major elements. Lionberger's 1960 "Adoption of New Ideas and Practices" [43] contains most of the elements of the diffusion model.

\section{Technology transfer as a field of study}

Technology transfer has a 60-year history of scholarship [44], with interest beginning primarily post World War II, and with periods of heightened interest in the Western world in response to events such as the Cold War, the development of the Space Age, and the emergence of economic competition in the 1970s [45]. In Canada, for example, the role of technology transfer has been spearheaded by the Federal Partners in Technology Transfer, while in the United States a legislative approach has been adopted; these different approaches to technology transfer have subsequently affected each country's progress. For instance, post World War II Canada was slower than its American and British counterparts to establish technology transfer policies [45].

\section{Evidence-based medicine as a field of study: An emerging emphasis in the health sciences}

In 1992 a new group and a new style of knowledge utilization emerged, heralded by the publication of the influential paper "Evidence-Based Medicine: A New Approach to Teaching the Practice of Medicine" [46]. This group of physicians declared a new way of doing medicine - one based on the explicit incorporation of empirical research findings into clinical decision-making processes. Their approach coincided, particularly in the United States, with increasing pressures to manage health care, in large part by reducing variation across both individual and group physician practices. They drew their lineage from the work of epidemiologist Archie Cochrane, who stressed the importance of evaluating medical interventions. Cochrane's work [47] had an important influence on the field of medicine and ultimately resulted in the establishment of the Cochrane Collaboration in 1993. Since the publication of the 1992 EBM manifesto, western society has witnessed a rapid emergence of numerous evidencebased centers, journals and resources.

\section{Intellectual mapping using citation analyses}

Bibliometric analysis (bibliometrics) uses citation data and quantitative analysis to trace published literature and to study the patterns of publication within a field. In analyzing scholarly fields, investigators map structures over time using techniques such as co-citation, co-word, and author co-citation analyses [[48], Chap 1]. In our work, we used ACA in the manner of White and McCain [49].

\section{What do citations measure?}

White and McCain argued that co-citation maps/citation analyses were powerful tools for mapping the intellectual structure of a field over time [50,51]. More recently, they reported longitudinal analyses of the structure and evolution of fields [49,52]. Small proposed that the cited documents are concept symbols [53]. Normative sociologists, among them Zuckerman [54] and Merton [55], viewed citations as markers of intellectual influence and as reward and payment of intellectual debts, respectively. Constructivists Latour [56] and Callon [57] viewed citation as a way of "enrolling allies" to strengthen one's own knowledge claims.

Merton argued that citations denote scholarly influence [58], that they can be used as a measure of scholarly value; they serve the instrumental function of transmitting knowledge, and the symbolic function of rewarding scientists by recognizing their intellectual property rights [59]. In short they are symbolic payment of intellectual debts [60]. Alternatively, constructivists such as Latour [56] have argued that authors use citations to legitimate knowledge claims. By citing another's work, an author strengthens his or her own knowledge claim by tying it to those cited. The social process of making knowledge consists of the successful alignment of initially diverse claims, and if the network is strong enough, the author's knowledge claim becomes an obligatory passage point [57]. Future authors wishing to make claims on the topic must go through this passage point (i.e., the author's work) by citing it. Consistent with Small [60], we argue that both normative and constructivist interpretations of citation patterns are valid.

\section{Author co-citation analysis}

In ACA, cited and co-cited authors are the unit of analysis [51]. As White and Griffith point out, "Co-citation of authors results when someone cites any work by any 
author along with any work by any other author in a new document of his own" [[61], p. 163]. Spatial maps are produced using one of a number of statistical techniques (e.g., cluster analysis, multi-dimensional scaling, factor analysis). Heavily co-cited authors appear grouped in space, with authors having many links occupying central locations on the maps and authors with weaker links (fewer co-citations) appearing on the periphery of maps [51]. White and McCain argued that ACA simplifies literatures to "writings by use" providing "a more rigorous grouping principle than typical subject indexing, because it depends on repeated statements of connectedness by citers with subject expertise" [[49], p. 329]. Several reports of ACA are available in the literature. White and Griffith covered seven years of the information science literature, finding identifiable author groups, which they call schools [61]. They identified border authors who connect areas of research. White and colleagues recently argued that co-citations reflect intellectual structure more strongly than they reflect social structure [22].

\section{Invisible colleges}

One of the uses to which co-citation analysis is put is the identification of invisible colleges $[62,63]$ - groups of elite, interacting scientists who are geographically dispersed, but who exchange information to monitor progress in their field $[40,64,65]$. Invisible colleges are generally agreed to represent social networks or significant thought (i.e., cognitive) collectives within a field. The former are commonly studied with sociometric methods, the latter with bibliometric methods. The emergence or strengthening of an invisible college on one hand or the weakening or loss of one altogether on the other, signal important changes scientifically and intellectually potentially serving to herald significant changes in the ongoing negotiations between science and society of their (sometimes uneasy) social contract. Author co-citation as a method maps intellectual structure, and does not provide direct evidence of social networks in a field.

\section{Purpose}

In the study reported in this paper, we undertook a domain analysis $[49,52]$ using bibliometric methods, specifically ACA to trace historical development of the field of knowledge utilization between 1945 and 2004. Our specific objectives were to map the development over time of knowledge utilization as a scientific field, and to identify the intellectual structure of this scientific community.

\section{Methods \\ Search Strategy}

We searched the Web of Science online database covering 1945 to October 2004 with combinations of keywords derived from concepts within the scope of the study (see Additional File 1 for the complete search strategy). Biblio- graphic information from 14,968 papers was downloaded. The goal of the search was for a balance between recall (exhaustivity) and precision (specificity). Recall is the number of relevant documents retrieved compared to the total relevant documents [66]. Our recall was $88.7 \%$, based upon how many of the possible 200 most cited documents were retrieved in our initial search. Precision is the number of relevant documents retrieved compared to the total documents retrieved [66]. We addressed precision by reviewing all titles and screening for inclusion/exclusion based on pre-determined decision rules. All reviewer pairs had an inter-rater agreement of more than $80 \%$, the first author reviewed the final exclusion decisions; 7,183 titles were excluded. More detailed methods are described in Additional File 2 and further additional information is available in the technical report on request.

\section{Data Management}

We removed 336 duplicates and 3,099 titles that were not "articles" (from the document type field), as articles most often represent new scientific production in a field of study $[67,68]$. From the initial 14,968 titles, 5,278 articles were retained. Data files were cleaned prior to analysis by correcting for variance in author name, cited author name, cited documents, journal name, and country, and the data were categorized by decade.

\section{Analysis}

Analyses were conducted for each decade starting with 1945. The data were analyzed using Bibexcel freeware, Excel, and Systat 4.0. Descriptive analyses - including most prolific countries, journals, cited authors, and cited documents - were completed by aggregating the data. For co-citation analysis, selection of authors was by frequency of citation. Selection of authors for co-citation analysis can be by a variety of means, such as personal knowledge, review articles, or directories $[51,63]$.

We produced maps for each decade using the twenty-five most cited authors. Twenty-five was chosen as a reasonable number of key authors to produce maps that were interpretable and not visually overwhelming. In one instance (1965 to 1974), 13 authors were chosen, as greater or less than 13 authors produced a map that was not readily interpretable. To create the author co-citation maps, co-citation matrices were first developed from raw citation co-occurrences using Bibexcel. The matrix of cocitation frequencies was entered into Systat 4.0, which uses a multidimensional scaling (MDS) algorithm to find the best-fitting two-dimensional representation of the matrix co-citation entries in the form of a visual map. We assessed the goodness-of-fit of each of the co-citation maps produced using Kruskal's Stress measure [51]. Values for Kruskal's Stress 1 [49] measure were 0.06, 0.16, 0.12 , and 0.13 for each of the decades respectively; a stress 
value less than 0.2 is considered acceptable [51]. We elected to present raw frequency maps because they were more interesting, with variation in the size of the nodes indicating frequency of citation. We reproduced our maps using Salton's cosine normalization $[69,70]$ and found no significant differences or changes to interpretation of the maps. The circles or nodes on the co-citation maps represent frequency of author citations; the lines joining the circles represent author co-citation [51,71]. Thicker lines and closer nodes indicate that the pair are co-cited more frequently, and therefore their work is considered to be conceptually similar [71]. We demonstrated structural change over time by producing a separate map for each decade [72]. The first map is for the decade of 1965 to 1974; prior to that there were insufficient authors to create meaningful maps.

\section{Results \\ Descriptive findings (mapping the field) \\ Domains and countries}

The number of distinct domains in which diffusion research occurred increases over time, with the largest increase in the 1995 to 2004 decade. Almost half of the articles $(2,363$ or $44.7 \%)$ identify the United States as their country of origin. The next largest producers are the United Kingdom and Ireland, with $13.1 \%$ of the articles (695), and Canada 7.6\% (400).

\section{Most prolific journals}

Table 1 lists the 20 most prolific core journals across all decades, and the total number of knowledge utilization articles published in each between 1945 and 2004. The wide variety in just the top 20 core journals (Table 1) shows a striking degree of inter-disciplinarity. Table 2 represents the five most prolific journals by decade. Between 1955 and 1964, publications in the journal Rural Sociology dominate. This is consistent with accounts that note that until the late 1960s most diffusion research took place in Rural Sociology [10,38]. In the next decade (1965 to 74), most diffusion publications are located in social science journals, and one library science journal. By 1979, the field of knowledge utilization had become sufficiently cohesive to warrant a specialist journal: Knowledge: Creation, Diffusion, Utilization (later called Science Communication). This journal is the core journal in the field for the next two decades. In 1985 to 1994 the Journal of the American Medical Association enters the field of core journals, and in the next decade (1995 to 2004), three of the most prolific journals are health journals.

\section{Most Cited Authors}

Table 3 indicates the top-cited authors in each decade in the reference lists of the 5,278 articles in the dataset categorized by decade. Table 4 shows the top-cited document in each decade. The top-cited author in 1945-1954 is H.
W. Seinwerth, an industrial relations manager from Chicago in the field of animal husbandry. In 1955 to 64, the top-cited author is Eugene Wilkening, a rural sociologist at the University of Wisconsin, Madison. His technical bulletin on improved farm practices is the top-cited document in this decade, reflecting the prominence of rural sociology in diffusion research at this time. Most citations across all decades (except 1945 to 54) refer to work in the diffusion of innovations field. This field is the parent domain, which arguably provides the conceptual and theoretical core for work in other domains. Everett Rogers is the most-cited author in all decades from 1965 to 2004 (Table 3), and various editions of his book, "Diffusion of Innovations", are the most-cited document from 1964 to 1994 (Table 4). In the last decade, Rogers' book is supplanted as most-cited document by what was to become the index paper for the newly emerging field of EBM [46].

\section{Longitudinal findings (the intellectual structure) The field over time}

In each decade, new and more robust domains emerged in the knowledge utilization field. A relatively small number of scientists, termed "core sets" by Harry Collins [73,74], played key roles in producing knowledge and resolving scientific controversies in this field. Core sets of scientists are not necessarily in frequent or sustained contact, and we distinguish them from collections of scientists such as invisible colleges who are closely connected. The term helps us to identify a small group of scholars who were actively engaged in the production and certification of knowledge. The core set authors are represented in the maps in Figures 1 through 4, and highlighted in Table 5 by decade. Scholars in the first decade (1965 to 1974) are from diverse disciplines (sociology, economics, geography, management, information science), but are linked by their work in innovation diffusion. Over time they become central figures in distinct subfields which represent their original disciplinary orientation. As noted earlier, prior to 1965 there were too few authors to create meaningful maps.

\section{5 to 1974}

Figure 1 shows the core, or parent domain, of diffusion of innovations, characterized by a cohesive [75] group of cocited authors linked by their common focus on aspects of the diffusion process and the gap between research and practice. The largest and most central node belongs to Everett Rogers, who in this decade published two editions of his groundbreaking work, "Diffusion of Innovations" [76] (the second edition was titled "Communication of Innovations: A Cross Cultural Approach" [77]). This work marks the first analysis of all known diffusion studies $[76,77]$, and the first, and most successful, attempt at articulating a general theory of diffusion. From the outset Rogers' representation of innovation diffusion theory 
Table I: Most prolific publishers of knowledge utilization articles (1955 to 2004)

\begin{tabular}{|c|c|}
\hline \# of articles & Journal Title \\
\hline 76 & Knowledge - Creation Diffusion Utilization* \\
\hline 66 & Technovation \\
\hline 60 & Journal of Advanced Nursing \\
\hline 59 & International Journal of Technology Management \\
\hline 53 & British Medical Journal \\
\hline 51 & Journal of Evaluation in Clinical Practice \\
\hline 48 & Technological Forecasting and Social Change \\
\hline 43 & IEEE Transactions on Engineering Management \\
\hline 42 & JAMA-Journal of the American Medical Association \\
\hline 41 & Research Policy \\
\hline 39 & Medical Journal of Australia \\
\hline 32 & International Journal of Technology Assessment in Health Care \\
\hline 32 & Journal of the American Medical Informatics Association \\
\hline 28 & $R$ \& D Management \\
\hline 28 & Management Science \\
\hline 27 & Medical Care \\
\hline 24 & Social Science \& Medicine \\
\hline 24 & Science Communication* \\
\hline 23 & Family Practice \\
\hline 23 & Journal of General Internal Medicine \\
\hline
\end{tabular}

*In September 1994 Knowledge - Creation Diffusion Utilization became Science Communication

constituted the main paradigm guiding intellectual work in diffusion of innovations.

Sociologist Elihu Katz' work linked disparate fields of diffusion research, such as communication and agricultural innovation $[78,79]$. Katz' and Rogers' nodes are close to and strongly linked to the nodes of sociologists James S. Coleman and Herbert Menzel, who worked with Katz on the social aspects of the diffusion among doctors of the new antibiotic tetracycline $[80,81]$. The widely cited study [81] highlighted the importance of interpersonal net- works in the diffusion of new medications and was a catalyst for future investigations in this area.

Close to Rogers' node is that of Edwin Mansfield, an economist then writing about the diffusion of innovations in business firms [82-84]. Mansfield's work is also linked to another economist, Zvi Griliches, who examined the economic factors affecting the diffusion of hybrid corn [85]. Thomas J. Allen's work is linked to Rogers through Mansfield. In this period, Allen studied research and development organizations, examining how engineers and scientists communicated and solved problems in organi- 
Table 2: Most prolific journals by decade

\begin{tabular}{cll}
\hline Decade & \# of articles & Journal title (date of first publication of journal) \\
\hline 1955 to 1964 & II & Rural Sociology (1936) \\
\hline 3 & Library Quarterly (193I) \\
\hline 3 & Sociometry (193I) \\
\hline 2 & $\begin{array}{l}\text { Social Forces (1922); Personnel Psychology (1948); Review of Economics and Statistics (1917); Human } \\
\text { Organization (194I); American Sociological Review (1936); American Documentation (1961); Administrative } \\
\text { Science Quarterly (1956) }\end{array}$
\end{tabular}

\begin{tabular}{|c|c|c|}
\hline 1965 to 1974 & 8 & Nauchno - Tekhnicheskaya Informatsiya Seriya I - Organizatsiya I Metodika Informatsionnoi Raboty (1967) \\
\hline & 6 & Administrative Science Quarterly (1956) \\
\hline & 5 & Human Relations (1947) \\
\hline & 5 & Special Libraries (1910) \\
\hline & 5 & American Behavioral Scientist (1957) \\
\hline \multirow[t]{5}{*}{1975 to 1984} & 35 & Knowledge - Creation Diffusion Utilization (1979) \\
\hline & 16 & Proceedings of the American Society for Information Science (1964) \\
\hline & 14 & R \& D Management (1970) \\
\hline & 9 & Administrative Science Quarterly (1956) \\
\hline & 9 & Rehabilitation Counseling Bulletin (1957) \\
\hline \multirow[t]{5}{*}{1985 to 1994} & 41 & Knowledge - Creation Diffusion Utilization (1979) \\
\hline & 23 & Technological Forecasting and Social Change (1969) \\
\hline & 23 & Technovation (198I) \\
\hline & 15 & Journal of Scientific \& Industrial Research (1942) \\
\hline & 12 & JAMA-Journal of the American Medical Association (1883) \\
\hline \multirow[t]{3}{*}{1995 to 2004} & 55 & International Journal of Technology Management (1986) \\
\hline & 52 & Journal of Advanced Nursing (1976) \\
\hline & 51 & Journal of Evaluation in Clinical Practice (1995) \\
\hline
\end{tabular}


Table 2: Most prolific journals by decade (Continued)

\begin{tabular}{ll}
\hline 48 & British Medical Journal (1840) \\
\hline 41 & Technovation (1981) \\
\hline
\end{tabular}

zations [86]. Although all three of these scholars were associated with technology transfer, the content of their work differed [21,87].

To the right of Rogers, and strongly linked to him and to Griliches, are geographers Torsten Hägerstrand and Lawrence Brown, who researched the spatial aspects of diffusion theory [88-90]. Hägerstrand also used Monte Carlo game theory to simulate the diffusion of farm practices $[91,92]$. To the left of Rogers are sociologist Alvin Gouldner, management theorist W. Jack Duncan and philosopher C. West Churchman. Gouldner [93] studied the differences between "cosmopolitans" and "locals" and the roles that they played in organizations. Duncan studied how to transfer management theory to practice [94], while Churchman studied the gap between managerial decisions and scientific knowledge $[95,96]$. At the bottom of the map, distant and not linked to the rest of the scholars, is Gerard Salton, an information scientist who examined the link between information dissemination and automatic information systems $[97,98]$.

\section{5 to 1984}

This decade shows a rapid uptake of diffusion scholarship. The parent domain diffusion of innovations grows, and two new domains emerge: knowledge utilization and technology transfer (Figure 2). Rogers' node remains the largest and most central on the map.

\section{Knowledge utilization}

The conceptual center of this new domain is the work of a new group of scholars - Carol Weiss, Nathan Caplan, and Robert Rich, all of whom investigate the use of social science research in public policy $[32,35,99]$. They are strongly linked to Rogers and the parent domain of diffusion of innovations. Their nodes are tightly clustered and strongly linked to each other, suggesting a high degree of conceptual similarity.

Moving out from the center are the nodes of Edward Glaser, Ronald Havelock, and Robert Yin. Havelock's early research $[19,100,101]$ examined how knowledge could be used to plan for innovation. Almost 15 years later, Glaser followed on this theme by co-authoring the influential "Putting Knowledge to Use: Facilitating the Diffusion of Knowledge and the Implementation of Planned Change" [36]. Yin's research is conceptually different, focusing on how new practices become routine [102], and the role of networking in knowledge utilization [103]. While Glaser and Havelock were not on the map for the previous decade (1965 to 1974), they were among the most cited authors, appearing on the map when we permitted 50 authors.

On the other side of the central core are Mark van de Vall, Ian Mitroff, and Robert Merton. Van de Vall's work was on the theory and methods used in applying social science research $[104,105]$. Sociologist of science Ian Mitroff was most cited for his 1974 book "The Subjective Side of Science", where he examines the wide gap between the finished products of scientific work (publications) and the actual processes of forming knowledge [106]. Merton is cited in this decade for the first and revised editions of his book: "Social Theory and Social Structure" $[107,108]$, and for his work on focused interviewing [109]. Merton is fairly strongly linked to fellow sociologist James Coleman, who also wrote on social theory, and received his

Table 3: Most cited authors by decade

\begin{tabular}{|c|c|c|c|c|c|}
\hline Decades & \# cites & Author name & Domain & Institution & Country \\
\hline 1945 to 1954 & 7 & Seinwerth, H.W. & Other & & USA \\
\hline 1955 to 1964 & 40 & Wilkening, E.A. & Diffusion of innovation, Agriculture, rural sociology & University of Chicago & USA \\
\hline 1965 to 1974 & 67 & Rogers, E.M. & Diffusion of innovation & Ohio State University & USA \\
\hline 1975 to 1984 & 155 & Rogers, E.M. & Diffusion of innovation & Stanford University & USA \\
\hline 1985 to 1994 & 198 & Rogers, E.M. & Diffusion of innovation & University of Southern California & USA \\
\hline 1995 to 2004 & 627 & Rogers, E.M. & Diffusion of innovation & University of New Mexico & USA \\
\hline
\end{tabular}


Table 4: Most cited publications by decade

\begin{tabular}{|c|c|c|c|c|c|}
\hline Decades & \# cites & Paper & Domain & Institution & Country \\
\hline 1945 to 1954 & - & All cited articles only cited once & - & - & - \\
\hline 1955 to 1964 & 9 & $\begin{array}{l}\text { Wilkening, E. A. (1952, May). 'Acceptance of } \\
\text { improved farm practices in three coastal plains } \\
\text { countries.' Technical Bulletin 98. North Carolina } \\
\text { Agricultural Experiment Station. }\end{array}$ & Diffusion of innovation & University of Chicago & USA \\
\hline 1965 to 1974 & 36 & $\begin{array}{l}\text { Rogers, E.M. (1962). Diffusion of Innovations. First } \\
\text { Edition. New York: The Free Press. }\end{array}$ & Diffusion of innovation & $\begin{array}{l}\text { Ohio State University, United } \\
\text { States }\end{array}$ & USA \\
\hline 1975 to 1984 & 70 & $\begin{array}{l}\text { Rogers, E.M. \& Shoemaker, F.F. (I } 971) \text {. } \\
\text { Communication of Innovations: A Cross Cultural } \\
\text { Approach.* New York: The Free Press }\end{array}$ & Diffusion of innovation & $\begin{array}{l}\text { Stanford University/University } \\
\text { of Denver }\end{array}$ & USA \\
\hline 1985 to 1994 & 89 & $\begin{array}{l}\text { Rogers, E.M. (1983). Diffusion of Innovations. Third } \\
\text { Edition. New York: The Free Press. }\end{array}$ & Diffusion of innovation & $\begin{array}{l}\text { University of Southern } \\
\text { California }\end{array}$ & USA \\
\hline 1995 to 2004 & 229 & $\begin{array}{l}\text { Evidence-based Medicine Working Group (1992). } \\
\text { 'Evidence-based medicine. A new approach to } \\
\text { teaching the practice of medicine.' JAMA, 268(17), } \\
2420-2425 .\end{array}$ & EBM & McMaster University & Canada \\
\hline
\end{tabular}

*Note: The second edition of Everett Rogers' 'Diffusion of Innovations' was co-authored with F. Shoemaker and published under the title of

'Communication of Innovations'. Subsequent editions were authored by Rogers only, and published under the name 'Diffusion of Innovations'.

PhD from Columbia in 1955, where he would have taken courses from Merton.

\section{Technology transfer}

There is no single conceptual core in this field in this decade, indicated by few links between individuals within the domain, but links back to the domain of diffusion of innovations. This is consistent with the widely differing interests of this core set of authors in the previous decade. Mansfield and Allen have moved in from the parent domain of diffusion of innovation. Mansfield's top citations are to works from the late 1960s and early 1970 s that examine the economic aspects of technological change in organizations [110-112]. Allen's most cited work is on research and development laboratories $[86,113,114]$. Geographer Brown is still strongly linked to that of Rogers in the parent domain, but Brown is also linked to the economist Mansfield through the work of Mahajan. A major contribution of Mahajan and of Peterson and Mansfield was to show how to fit mathematical models to diffusion data.

\section{5 to 1994}

There are three trends in the 1985 to 1994 decade (Figure 3 ). First is the emergence of EBM as a distinct domain. Second, the domain of diffusion of innovations shrinks in size, although Rogers' node continues to dominate the map (Rogers published another edition of his book in this decade). Third, the knowledge utilization field became more homogeneous and stronger. Two new journals started during the previous decade created arenas in which scholars in knowledge utilization and diffusion could exchange ideas and develop the interdisciplinary application of science knowledge [21]. The emergence of these and other journals and societies are indicators of growing disciplinary cohesion. Authors who remain highly cited in the knowledge utilization domain comprise the current intellectual core set of the field, while authors whose work has not continued to be central to the domain of knowledge utilization exit the map, among them Van de Vall, Mitroff, Merton, and Yin.

\section{5 to 2004}

The map for 1995 to 2004 (Figure 4) shows a continuation of the trends that emerged in the previous decade, especially the growth of EBM. The separate domains show increasing conceptual cohesion internally - citation nodes move closer to each other within the field, and the domains as wholes are more easily distinguishable from the other fields.

At first glance, it appears that the other domains have gotten smaller in this decade. Sociologist James Coleman's early tetracycline study [80] reappears in this decade in the domain of diffusion of innovations. Although White and McCain argue that the reappearance of older work may indicate the revival of a domain [49], we attribute the reappearance of this one work to its relevance to the new EBM project. Coleman is also highly cited in works related to the diffusion of innovations within healthcare [115-117]. 
Table 5: Core-set authors by decade by domain

\begin{tabular}{|c|c|c|c|}
\hline & 1975 to 1984 & 1985 to 1994 & 1995 to 2004 \\
\hline \multirow[t]{9}{*}{ Knowledge utilization } & Caplan & Bozeman & Backer \\
\hline & Glaser & Backer & Caplan \\
\hline & Havelock & Caplan & Havelock \\
\hline & Merton & Dunn & Weiss \\
\hline & Mitroff & Glaser & \\
\hline & Rich & Havelock & \\
\hline & Vandevall & Rich & \\
\hline & Weiss & Weiss & \\
\hline & Yin & & \\
\hline \multirow[t]{10}{*}{ Diffusion of innovations } & Aiken & Kimberly & Brown \\
\hline & Brown & March & Coleman \\
\hline & Coleman & Rogers & Katz \\
\hline & Downs & Zaltman & Rogers \\
\hline & Feller & & Zaltman \\
\hline & Hage & & \\
\hline & March & & \\
\hline & Rogers & & \\
\hline & Utterback & & \\
\hline & Zaltman & & \\
\hline \multirow[t]{10}{*}{ Technology transfer } & Allen & Allen & Allen \\
\hline & Federal Insurance & Bass & Mansfield \\
\hline & Corporation & Jensen & Mahajan \\
\hline & Mahajan & Mahajan & Nelson \\
\hline & Mansfield & Mansfield & Rosenberg \\
\hline & Vernon & Nelson & \\
\hline & & Reinganum & \\
\hline & & Rosenberg & \\
\hline & & Sharif & \\
\hline & & Teece & \\
\hline \multirow[t]{11}{*}{ Evidence-based medicine } & & Eddy & Chalmers \\
\hline & & Haynes & Davis \\
\hline & & Lomas & Eddy \\
\hline & & & Grimshaw \\
\hline & & & Guyatt \\
\hline & & & Haynes \\
\hline & & & Lomas \\
\hline & & & Oxman \\
\hline & & & Sackett \\
\hline & & & UK Dept Health \\
\hline & & & Woolf \\
\hline
\end{tabular}

Other Burt

In this decade, the most cited article is the index EBM paper [46]; with its spread, the term EBM enters the lexicon. The paper was published in a highly visible and easily accessed medical journal and its author group included 29 members, among them Guyatt, Haynes, Oxman, and Sackett (chair of the group). The authors continued to cite the original paper, toured and gave numerous talks [118121]. Their work coincided with emerging concerns about rising health care costs and increasing accountability pres- sures, such as have been described by Nowotny and others [1,122-124].

\section{Canonical authors and canonical works}

White and McCain [49] define a canonical author as someone who appeared on the citation maps in three or more decades. We identify seven canonical authors whose work has enduring importance to the field and who were on at least the last three maps (1975 to 2004). We argue that the most cited works of these authors constitute the 


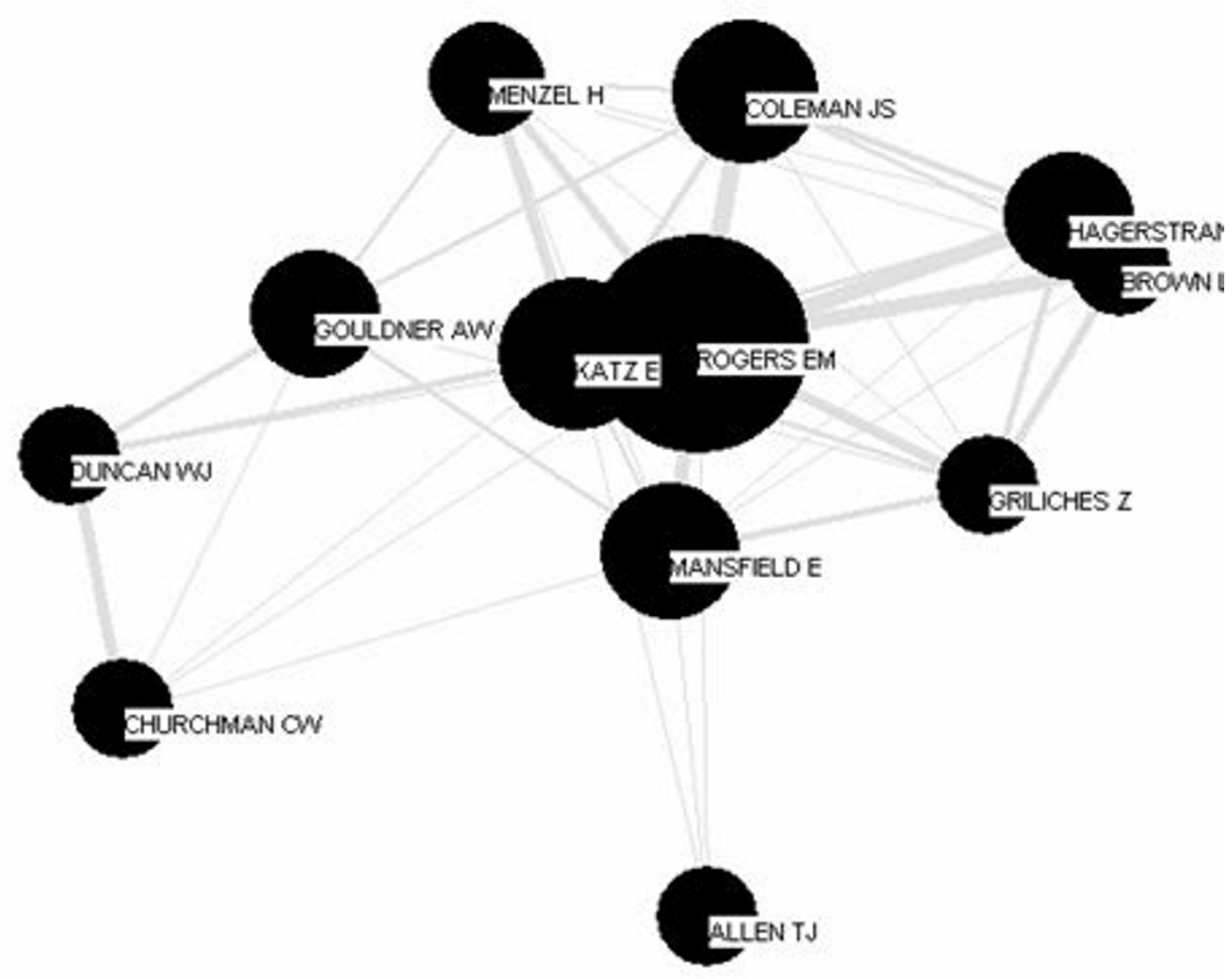

Figure I

First author co-citation map 1965-1974. 


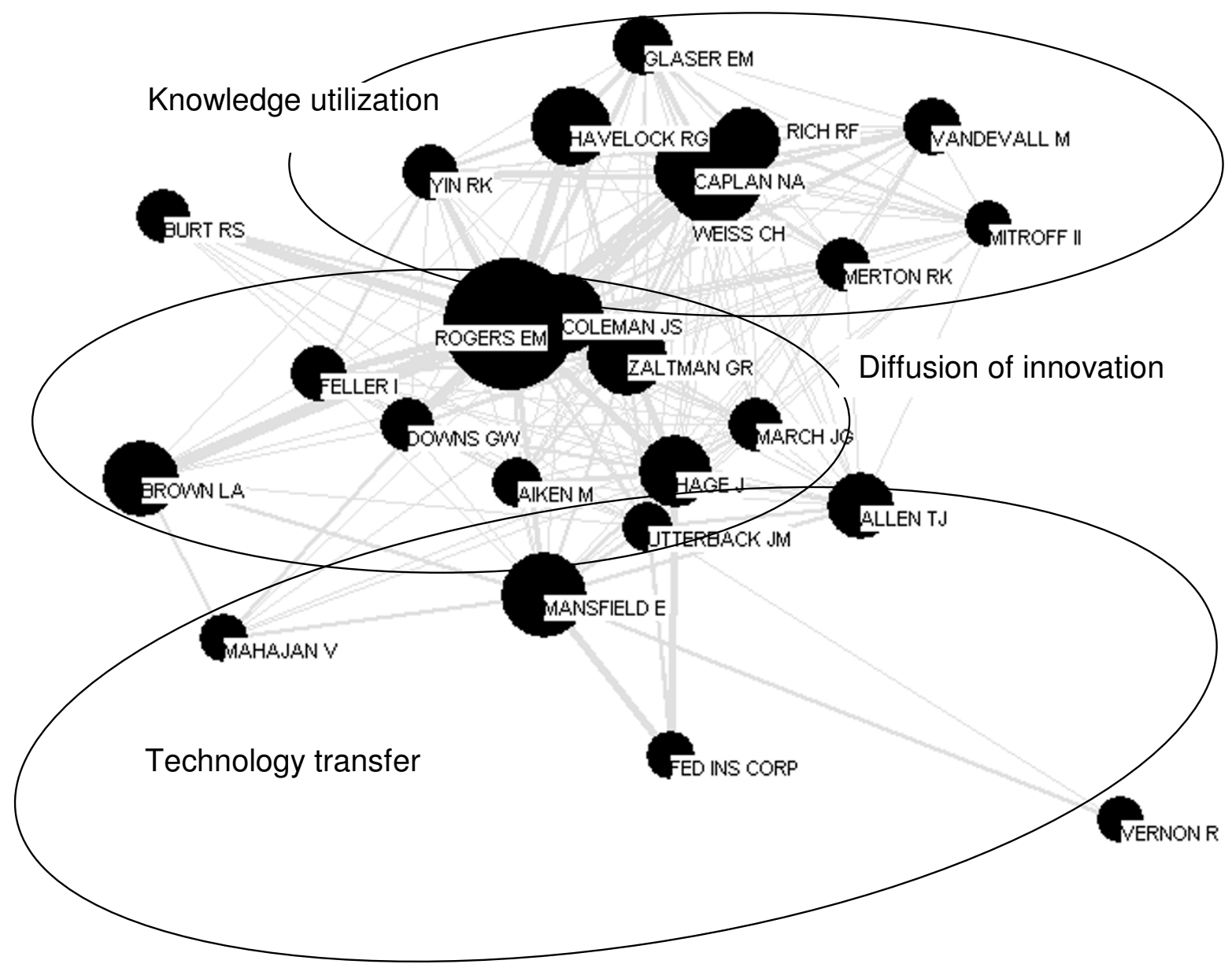

Figure 2

First author co-citation map 1975-1984.

canonical literature of the science of knowledge utilization as it entered the twenty-first century. These canonical authors are: Everett Rogers and Gerald Zaltman (innovation diffusion), Carol Weiss and Ronald Havelock (knowledge utilization), and Edwin Mansfield, Thomas Allen, and Vijay Mahajan (technology transfer). Rogers, management scientist Allen and economist Mansfield are the only authors who were top-cited in all decades, excluding 1945 to 1954.

The intellectual structure of the field in all decades is dominated by the work of Everett Rogers. His theory has been the dominant and most consistently used theory since inception of diffusion research $[125,126]$, and is emblematic of the diffusion paradigm until the emergence of EBM in the last decade. We argue that Rogers is a canonical author [49], that his book "Diffusion of Innovations" is a canonical text for all the domains, and that his approach to innovation diffusion represents the dominant paradigm for conducting diffusion research. "Diffusion of
Innovations", first published in 1962, went through five editions before his death in 2004 (1971, 1983, 1995, 2003) $[10,76,77,127,128]$. Each edition of his book was based on an analysis of all retrievable diffusion studies. The presence of such a dominant author stands in contrast to, for example, the information sciences field, characterized by the absence of a strong central author [49]. It also stands in contrast to some of our own canonical authors such as Mansfield, whose early publications are the only work top-cited in all decades.

\section{Diffusion of innovations}

In addition to Everett Rogers' canonical status in this domain, Gerald Zaltman's most cited works were "Innovations and Organizations" [129] and "Strategies for Planned Change" [130]. While Zaltman's work was strongly pro-innovation, it also reflected a belief that innovation should not be accepted unquestionably. He showed the importance of individual users of innovations to the diffusion process, and he proposed that to under- 


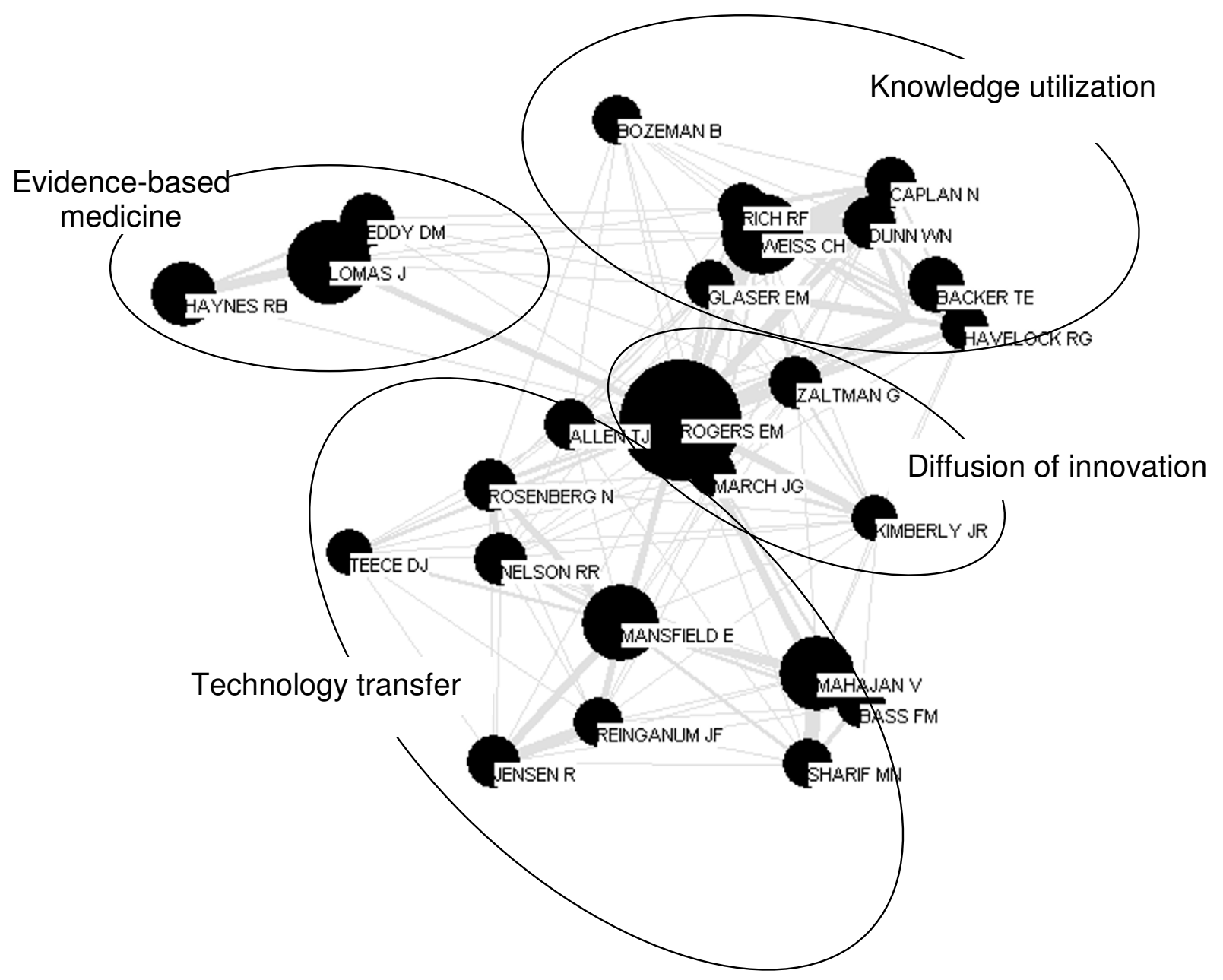

Figure 3

First author co-citation map 1985-1994.

stand how innovation diffusion truly occurs we need to study demand characteristics, such as users' ability and willingness to seek and process innovations.

\section{Knowledge utilization}

Carol Weiss was most cited for her works "Knowledge Creep and Decision Accretion" [35] and "Using Social Research in Public Policy Making" [131]. She continues to publish [132,133], and has expanded initial views of research use as an instrumental application of research to inform a decision, to include conceptual or enlightened use - when findings from research influence decision makers' attitudes to and perceptions of a social problem [134]. She described several models of utilization: knowledge-driven, problem-solving, interactive, political, tactical, and research as part of the intellectual enterprise of society [34]. An advocate of using research findings to inform public policy, she was among the first to examine the utilization of evaluation findings in improving pro- gram processes and program outcomes [135]. Her articulation and extension of the concept "research utilization" was an important contribution to the field of knowledge utilization [34].

Ronald G. Havelock is recognized for his extensive work on knowledge use, change planning, and technology transfer. Author of "Planning for Innovation through the Dissemination and Utilization of Knowledge" [101], his work spanned many fields including education and medicine. Building on Rogers' work [76], Havelock developed a framework which aided in the understanding and improvement of the dissemination and utilization of knowledge in the social sciences. Guided by an extensive analysis of this literature from education and beyond, he proposed an often cited "linkage model" that connects researchers with end users in a two-way exchange of information that mutually enhances problems solving. 


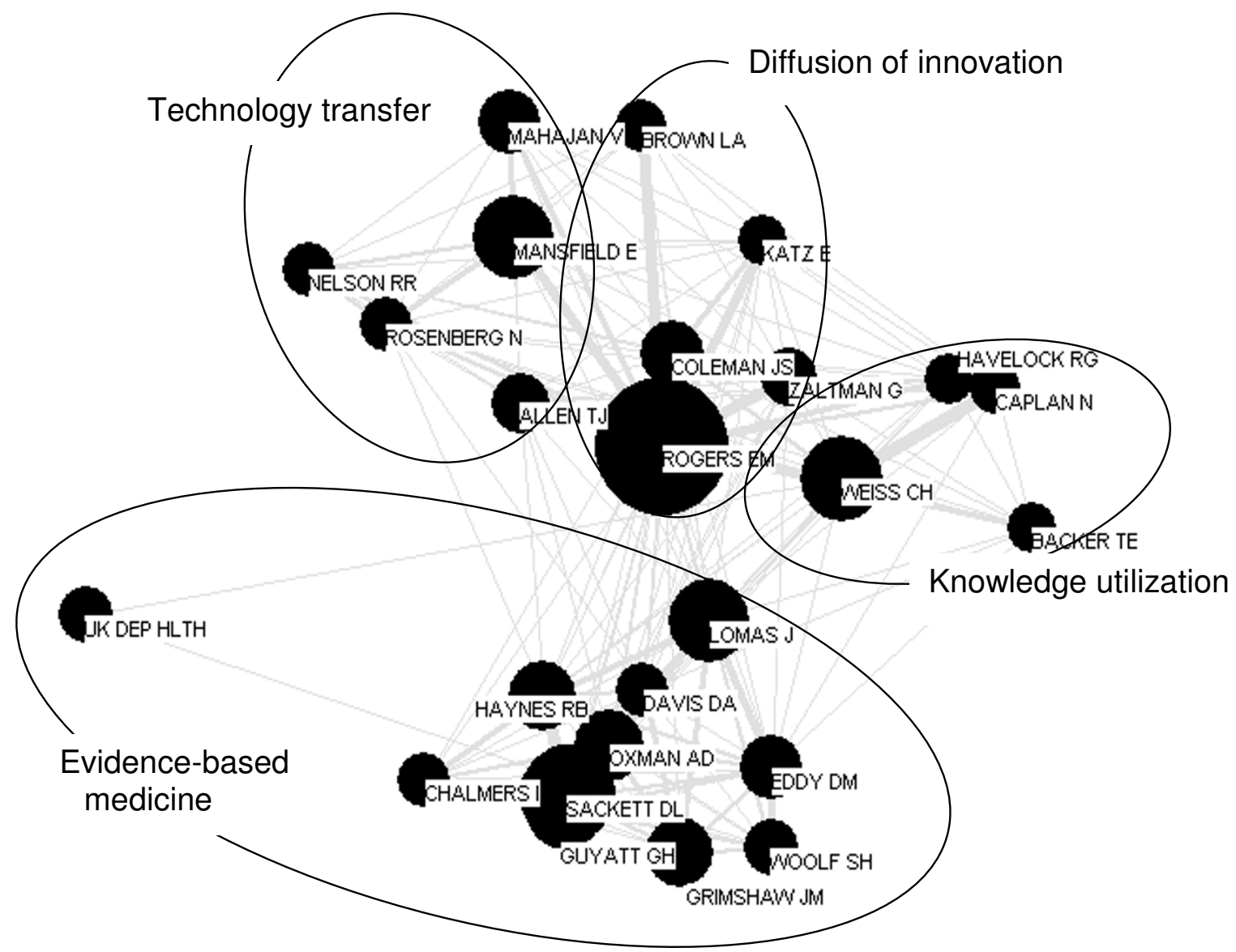

\section{Figure 4}

First author co-citation map 1995-2004.

\section{Technology transfer}

Edwin Mansfield's early work from the 1960s formed "concept symbols" for the domain [53] and exerted a continuing impact on the field [110-112]. An influential economic analyst of technology, he explored the length of time required for firms to uptake decisions and products used by rival firms, and how this information is spread from one firm to the next. He also studied the proportion of new products and processes that are based on academic research, and the amount of time needed for such research findings to be incorporated into the commercial environment.

Among other contributions, Thomas J. Allen studied the influence of distance on information transfer and developed the Allen curve, which depicts the inverse relationship that exists between distance and the frequency of communication $[86,113,136]$. Allen also studied the ways in which formal and informal associations within organizations contribute to the diffusion of knowledge. He identified "gatekeepers" as important individuals within organizations who bring new knowledge into their organization both by reading literature and by engaging with others outside of the organization. He found that new ideas are spread most commonly through informal mechanisms such as personal contact.

Vijay Mahajan wrote on developing knowledge in the areas of marketing strategies, product diffusion, and research methodology. He is responsible for adding the temporal element into a model originally designed by Blackman [137] to explain technological substitution. Mahajan has made important contributions in the area of product diffusion and has studied the diffusion process in developing countries, which he argues is an important but understudied area $[138,139]$. A more detailed version of the longitudinal findings is available in Additional File 3.

\section{Discussion}

We set out to trace the historical development of the field of knowledge utilization by mapping its development over time, and identifying the intellectual structure of this 
scientific community. The major contribution of this paper is its overview of the field and how the field has changed over time. In this discussion, we contextualize the major findings and expand on four discussion points: development of the field, its specialization, and changing perspectives; our inability to claim that this field (perhaps emerging discipline) is pre-paradigmatic; the emergence of Everett Rogers as a canonical figure in the field; and; the emergence of a new domain, EBM, within the knowledge utilization field.

The maps in Figures 1 through 4, compiled from aggregate author co-citation data, link oeuvres and offer a panorama of the changing intellectual structure of the field, showing the "history of the consensus as to important authors or works" [[50], p. 100]. White and Griffith describe oeuvres as a set of writings by a co-cited author [61]. While an author's node on the map likely represents more than one of their publications, it does not guarantee that all of the author's publications are represented. The only works that will be represented are those that are co-cited with the other authors in the analysis. So, for example, someone might write one article early in their career that is cited for many years, but other works by the same author might not be co-cited.

\section{Development of the field and its intellectual history}

Our first major finding is that new domains within the field now generally referred to in the literature as knowledge utilization have emerged over time; in earlier generations, the term most widely used was innovation diffusion. We argue that although all of the domains we identify are concerned with the use of knowledge in some way, they change and take on distinct specializations and perspectives over time and continue to be strongly linked to innovation diffusion. This finding is in contrast to White and McCain's longitudinal ACA of the information science literature, where they found tremendous inertia, or lack of change over time [49]. They argue that their maps could have looked different at the separate time points if there had been major changes in the field. Our maps do look different in each decade, reflecting continuing change and growth in the intellectual structure of the field. The 1965 map represents authors from a wide variety of academic disciplines whose common object of inquiry is conditions surrounding the use or application of scientific knowledge. In the 1975 to 1984 decade knowledge utilization and technology transfer emerge as distinct areas of study, and in the 1985 to 1994 decade EBM emerges. Over the decades new areas emerged, centered on the work of canonical authors who were already working in the field, before it divided into subfields.

The origins of this broad knowledge utilization field lie in the study of the diffusion of agricultural innovations in rural sociology, credited by Rogers as dating back to Ryan and Gross' hybrid corn study. In a modified co-citation analysis of the diffusion of innovation and technology transfer literature between 1966 and 1972, Cottrill, Rogers, and Mills found that the majority of the members of their diffusion of innovations cluster were from sociology [21]. In Table 4, Wilkening's work on the diffusion of agricultural innovations is the most-cited work in the 1955 to 1964 decade. By the late 1960s, research on the diffusion of innovations in rural sociology had virtually died out, possibly because it solved the particular problem of producing and disseminating means by which high yield crops are produced.

A second important finding is that, over time, the initial core set of authors in diffusion research branched off to become the intellectual center of their new fields. In other words, new fields branch off from the original field of innovation diffusion, and at the core of each of these new fields (with the exception of EBM), we see one of the authors in the first or second decades. Rogers and Mansfield emerge from the first decade as central to innovation diffusion and technology transfer in later decades, respectively. Weiss, Caplan, and Havelock appear in the third decade and remain in each subsequent decade under the knowledge utilization domain. EBM first appears in the 1985 to 1994 decade with three authors, Eddy, Haynes, and Lomas. Lomas is a border author providing the primary connection between EBM and innovation diffusion (and to a lesser extent knowledge utilization) [61].

\section{Challenging Kuhn's notion of pre-paradigmatic: The diffusion of diffusion}

The social sciences have been characterized, most famously by Kuhn, as being "pre-paradigmatic," a state where no accepted set of principles or theories guide research in the area [140]. Although sometimes disputed, Kuhn suggested that the social sciences were characterized by disagreement and lack of consensus, and argued that the natural sciences are characterized by long periods of normal science, where practitioners are guided by a single theoretical model, which aids them in solving puzzles that fit within the paradigm. In 1979 Small and Crane found evidence that the fields of economics, psychology, and sociology were developing in a manner more characteristic of the natural sciences [75]. Kuhn further argued that natural science does not progress in a cumulative fashion, but instead is punctuated by revolutions that radically alter the theoretical rules that inform practice. Here, in the overarching field of knowledge utilization, we find no evidence of the fragmentation and allegiance to multiple-paradigms predicted by Kuhn [140].

Valente and Rogers claim that the pre-paradigm period in innovation diffusion was in the 1930s [38], and that the paradigm was set by Ryan and Gross [141]. Although in 1983 Rogers claims the Ryan and Gross article as the top 
cited one in diffusion literature [127], our analysis found that that various editions of Rogers' books are by far the highest cited documents in the innovation diffusion literature. Our findings also provide strong evidence that this social science field is more like Kuhn's portrayal of the natural sciences during periods of normal science. There is a paradigm from the beginning - when Rogers publishes the first edition of his book. We believe that Rogers' work had such a significant impact because it was the first, and continued to be the only work, by virtue of its ongoing syntheses, that described (at least his representation of) a general theory of innovation diffusion. Further, Rogers' synthesis of most known empirical studies of diffusion remained useful to scholars.

If Kuhn's claim of the social sciences as pre-paradigmatic is correct, then in knowledge utilization we have an atypical social science field, growing in an atypical way. The maps show growth and specialization over time, not fragmentation as predicted by Kuhn. The knowledge produced about diffusion is taken up and used - it does not languish. People on this map share many assumptions, and their intellectual debt to the work of Everett Rogers shows in the persistent size of his node, and in the strong links to each newly emerged field, including EBM. Zuckerman argued that citations indicate intellectual influence [54]. If so, no single person has been more influential in this field than Rogers; many if not most on this map share an intellectual debt to him. Rogers put forth a representation of a "generalized model of diffusion" [[142], p. 16] in his first book [76] and "set forth common findings to date, arguing for a general diffusion model, and for more standardized ways of adopter categorization" [[142], p. $16]$.

Although the study of diffusion in rural sociology became exhausted in the 1960s [38], Rogers argued [[142], p. 19] that diffusion research was not dead or dying: "The number of diffusion publications completed per year continues to hold steady. Unlike most models of human behavior that begin to fade after some years of use, the diffusion model continues to attract strong interest from scholars." We also did not find a 'fading' of the diffusion paradigm. Our citation maps show that there is not a shift away from the diffusion paradigm; rather, there is a spread of the paradigm to other fields and areas of specialization. We do see, however, from the titles of the articles of the most-cited authors, a content shift away from the concerns of agriculture.

\section{The influence of Everett Rogers}

Everett Rogers, with the publication of his 1962 book, became an obligatory passage point [57]. His continued publication of updated editions of that book $[10,76,77,127,128]$ ensured that he remained an obliga- tory passage point making it, we propose, nearly de rigueur to cite Rogers when writing in the knowledge utilization field. This may change if EBM continues its explosive growth; we observed that its proponents were less consistent in their citation of Rogers than those in other subfields.

Rogers is generally viewed as one, if not the most influential, social scientists of the last one hundred years. His book is the second most cited in the social sciences [143]. Some reasons for this influence are obvious. He worked in several universities (among them Iowa State, Michigan State, University of Southern California, University of Michigan, University of New Mexico) and had many academic associates, among them some of the original diffusion scholars - Beal, Coleman, Gross, Ryan, and Wilkening. He worked on projects in many countries; he was invited to speak widely and often. He had many graduate students and colleagues and was known for his generosity and gift for bringing people and institutions together. He shared authorship and ideas widely.

Sociologist of science Knorr-Cetina argued that each of the sciences produces knowledge in a different way [144]. For example, in molecular biology, she argued that scientist's biographies affect their epistemology - that through their careers their bodies become finely tuned measurement instruments, learning to perform delicate operations that cannot be taught. In much the same way, there is evidence that Rogers' personality and his way of doing research his epistemology - was an embodiment of the same networking principles which he studied. His personal biography embodied his theorizing. After Rogers' death, four of his former students recalled their personal associations with him [145]. Thomas Backer recalled that "Ev had a remarkable gift for bringing together people and institutions that otherwise didn't talk to each other much - he was the best example in the world of the kind of natural networker he studied in his research" [[145], p. 291], and well known for his enthusiastic ability to "help connect people he thought should know each other, or who could work with him on a project" [[143], p. 285]. James Dearing, argued that "Perhaps intuitively, Ev understood the social capital advantages of heterophilous relationships" [[145], p. 294]. Thomas Valente wrote that after the first conference on Entertainment Education in 1989, Rogers invited everyone to his house for dinner. It became a "raucous celebration," and he goes on to note that "[e]veryone who was there marks it as the time when entertainment education became a cohesive field of scholarship" [[145], p 297].

Rogers lived a long and productive life. He completed his doctoral work in 1957 at the age of 26, and remained active as a scholar for the next 47 years. He wrote 36 books 
and more than 350 refereed journal articles [145] including a new edition of his well known "Diffusion of Innovations" about every ten years $(1962,1975,1983,1995$, 2003). His last published paper appeared posthumously in 2005 [146]. In it, Rogers reflected on his own unique place in the emergence of the diffusion model and on the model's origins in the literature review chapter in his dissertation. Of central importance is that he created a common language with which scholars could talk about diffusion - by emphasizing the term diffusion "rather than the plethora of terms that had been used for this concept" [[142], p. 16]. He concluded that "... it seems there is indeed a general diffusion model" [[142], p. 19].

From a science studies perspective, by studying every known diffusion study regardless of discipline, Rogers unknowingly enrolled thousands of allies to his cause [56]. We do not claim that this was his intent, but by taking something from a wide range of fields (the empirical studies of diffusion), and by giving back something to every field (a general theory of diffusion and a common language), Rogers built a formidable knowledge claim. It is also important to note, however, that citation studies find that authors are cited for their usefulness and for their merit. The story could have unfolded differently if the scholars in the field had not found Rogers' representation of innovation diffusion theory to be of use in solving problems in their own areas. In other words, Rogers is not important just because he studied all known diffusion studies, but because he did this and produced a useful representation of diffusion theory; he got it right, so to speak. His representation of innovation diffusion theory has been shown to be stable and of use to a wide array of scholars in diverse fields. However, getting it right is no guarantee of success. The history of science is replete with people who got it right but who were not credited as such, or people that only time proved were right. Perhaps most famously, in the nineteenth century Pasteur's germ theory won out over Pouchet's theory of spontaneous generation - not because the evidence supported Pasteur, but because in part at least, the members of the French Académie des Sciences were biased in favor of Pasteur. At the time, an "evidence-based" decision would have supported Pouchet's theory [147]. In addition to getting it right, success of the kind that Rogers and the theory of innovation diffusion have earned over the decades is a complex blend of crafting and winning credibility among peers [148], and having one's knowledge claim noticed and taken up by some relevant community $[56,74]$.

\section{The emergence of evidence-based medicine}

In this paper, we have presented a largely descriptive picture of the growth of the field known broadly as innovation diffusion. We have shown that until recently, research in this field has been informed largely by one the- oretical paradigm, laid out in the work of innovation diffusion scholar Everett Rogers. We have shown how the field began with a core set of scholars from many disciplines with a common interest in innovation diffusion. We have shown that, over time, this core set of scholars formed the core of new, but related fields. We demonstrated that in the mid-1980s another field emerges (EBM). This field is linked intellectually particularly to Everett Rogers, primarily through the work of Jonathan Lomas, who is strongly linked to Haynes in EBM. The work of Eddy pulls more widely from the field of knowledge utilization, as well as from scholars in the parent domain of innovation diffusion. In the 1990s, we see the field of EBM growing and drawing from the fields of technology transfer, knowledge utilization, and innovation diffusion. Terminology, even in this subfield and within the health disciplines, is complex. For many groups working in the field that we have labeled with the cover term EBM, a broader cover term will be necessary. One sees for example terms such as evidence-based practice, evidencebased nursing, evidence-based decision-making, and evidence-informed decision-making used widely.

We argue that the rapid emergence of this new domain is possible because its adherents practice a form of knowledge production and scientific output that differs significantly from those in related fields. This production of outputs is characterized in particular by an emphasis on systematic reviews of the research literature. Its adherents tend to publish in journals with unusually high impact factors and wide dispersion. Their emphasis is arguably more vigorously focused on instrumental and normative ends (the use of clinical research to improve outcomes), and their emergence coincided with emerging foci on accountability and cost containment, and more recently foci on value for money and accountability for performance in health services. Although not yet apparent in this decade, it is likely that subsequent decades if mapped with a wide enough net will reveal an explosion of related fields within EBM, comprised at least of quality improvement and safety subsets. EBM adherents may represent a new epistemic culture of knowledge production [144].

We propose that it is the EBM Group's emphasis on systematic reviews and their active dissemination and transformation, coupled with a highly normative and prescriptive orientation, that creates the conditions for this new form of knowledge production. Rogers, working without the aid of computer databases (for much of his early career at least) also synthesized, pouring laboriously through all known diffusion studies. In this regard there are similarities. Rogers' goal, however, was a synthesis and representation of a general theory of innovation diffusion. EBM's goal is prescriptive while being rigorously empirical - to guide and inform medical practice, working from a 
model in which the 'gold standard' in medical knowledge has been defined. Rogers sought to understand the process of how new innovations were diffused. EBM may be creating by example a new way of diffusing innovations. Its members have used the innovation diffusion literature and are linked in many ways to this literature. But this epidemiology based group has not as yet evidenced an intent (nor we argue should they necessarily) to build theory about knowledge utilization, technology transfer, or innovation diffusion. Rather, it is highly prescriptive and characterized by a strong underlying assumption that practitioners of EBM have (or can get) the best knowledge and the best knowledge production model. They are linked to the original problematic of innovation diffusion through the age-old problem of the know-do gap [149].

\section{Limitations}

Most of the limitations of this study are typical of bibliometric studies generally, including the inclusiveness of the Web of Science, inaccuracies in the databases, analysis by first authors only, and limited knowledge of the context of citation. We chose the Web of Science because it contains all of the necessary fields to conduct bibliometric analysis and is a multidisciplinary database [150]. The Web of Science, however, does not represent all disciplines equally and therefore knowledge utilization articles within sciences or health care are more likely to be represented than knowledge utilization articles within the social sciences. Publication counts, such as number of publications by author or country, number of journals, etc., are therefore biased toward science and medicine. However, citation analysis such as ACA is not affected by the journals indexed in the Web of Science, because all cited documents are listed regardless of whether or not the journal is indexed in the database. Spelling and bibliographic variances are common in databases [151], and can cause errors in publication counts. We corrected for these variances by undertaking a detailed manual review and correction of variances. Lastly, conducting analyses by first authors attributes all contributions of a work to only the first author.

Three specific criticisms are leveled at author co-citation. First, resulting maps may omit authors an informed reader may view as central [50]. In this case, the reader may disagree (as he or she is free to) with our judgment sample. Second, such maps may fail to reflect an informed reader's knowledge of new directions to which authors' recent papers and interests may have led [50]. This is unavoidable, but such directions can be traced and assessed with future analyses. Third, a more fundamental epistemological criticism exists - one which asks whether the maps yield the true picture. However, it is unlikely that there is any one true picture; all maps leave some information out, and include other information. If a reader's views differ from ours, whose view is preferred? In response, White has argued: "... the status of the maps is neither preferred nor nonpreferred a priori; it must be decided in light of the claims being made and the overall evidence brought to bear" [[50], pp. 100-101]. It is also the case however that these maps have been quantitatively validated as being quite congruent with data collected independently from scholars in the field [52]. Finally, given publication delays of sometimes up to two years, it is unlikely that we have captured the state of science in the field beyond about 2002. A limitation of this and similar studies is the effect of partitioning on papers/author/journals published toward the end of the decade. These have a lower likelihood of being cited than do those published toward the beginning of the decade. We could also have restricted the cited year window, by only accepting citations, for example, not older than 10 years. Had we done this, it would have resulted in a more dynamic picture focusing more attention on currently active scholars. However, we were interested in an historical, longitudinal mapping, and including older citations was important to see work that has continued to be cited actively.

\section{Conclusion}

In this paper, we used ACA to show that new forms of knowledge production and utilization - in particular, EBM - are emerging and are rapidly accelerating. It might seem that EBM has no relation to the hybrid corn study of so long ago, or innovation diffusion as a field. Our longitudinal analysis shows clearly, however, that this new field of activity in the medical sciences has strong intellectual roots and is indebted to the social science discipline of innovation diffusion. The relevance of such a finding lies in the particular pattern of emergence of EBM. We argue this pattern is representative of a broader societal shift to a different form of knowledge production than has characterized innovation diffusion for almost six decades. With this shift, the social contract between science and society is undergoing a renegotiation, a renegotiation with society as a far more active partner in the creation of knowledge.

Gibbons and Nowotny $[1,152]$ have characterized this renegotiated form of science as mode two knowledge production. They have described it as involving non-hierarchical relationships with stakeholders, such as industry, government, and health care decision-makers. Its features are: knowledge production in the context of application, transdisciplinarity, a much greater diversity of sites of knowledge production, high reflexivity, and novel forms of quality control [123]. Such mode two knowledge production, based on the needs of end users in the health care system, is arguably a more socially accountable form of knowledge production. This is in contrast to mode one production that reflects what have historically been the 
traditional, academic norms of scholarship in the disciplines and institutions in which researchers work, such as academic tenure and promotion based on high impact, peer-reviewed publication [1]. The foundations of mode one production rest on principles of scientific expertise, peer review, and non-interference.

The health care environment is characterized by ever increasing demands for accountability in the wake of troubling reports suggesting that quality of care is less than optimal $[12,14]$. This, coupled with unusually high volumes (relative to the social sciences, for example) of peer reviewed outputs from elite medical researchers, creates at least two of the necessary conditions for the rapid emergence of a new domain, namely EBM. The study of this new domain will be of interest to a wide range of scholars, for example those interested in bibliometric methods, those studying the sociology of knowledge, and those engaged in science studies. The emergence of EBM is also a potentially compelling story in its own right, and one deserving of a detailed examination. The first 15 years of its history currently reside in its artifacts (a central example of these artifacts being peer-reviewed papers). Its originators are also still actively engaged in creating its history. In this regard, we can do better than history of the cliometric sort suggested by White and McCain [[49], p. 327]:

"Because the data of ACA are merely noun phrases and associated citation counts, they produce history of the cliometric sort, which leaves out almost all the good parts, such as who had shouting matches, who slept with whom, and what actually gave rise to the most significant work."

Few social science studies provide the "good parts", or the good parts are written out in an attempt to make a qualitative analysis sound more objective. In this analysis we argue that the emergence of EBM is a striking example of a shift in knowledge production mode that is actually a "part" worthy of closer examination.

\section{Competing interests}

The authors declare that they have no competing interests.

\section{Authors' contributions}

CE conceived the study and its design, secured funding, provided leadership and coordination, participated in data analysis and interpretation, drafted the final manuscript, and approved the final submitted manuscript. LD conducted data analysis and made major contributions to interpretation of findings, writing, and in providing critical commentary. JL participated in designing the study, securing grant funding, participated in all team meetings providing critical and substantive commentary to both process and final products. CW coordinated and conducted all searches, ran all analyses, produced all maps, figures, and tables, and contributed to writing the final manuscript. LW, SS, and JPM participated in study design, all team meetings and data interpretation; provided input into the writing of the manuscript. All authors read and approved the final manuscript.

\section{Additional material}

\author{
Additional file 1 \\ Search strategy. A complete search strategy used in the Web of Science to \\ obtain bibliographic data for this bibliometric study \\ Click here for file \\ [http://www.biomedcentral.com/content/supplementary/1748- \\ 5908-3-49-S1.doc]

\section{Additional file 2} \\ Detailed methods. A more detailed description of the bibliographic/ACA \\ methods used in this study \\ Click here for file \\ [http://www.biomedcentral.com/content/supplementary/1748- \\ 5908-3-49-S2.doc]

\section{Additional file 3} \\ Detailed findings. A more detailed description of the bibliographic and \\ longitudinal ACA findings of this bibliometric study \\ Click here for file \\ [http://www.biomedcentral.com/content/supplementary/1748- \\ 5908-3-49-S3.doc]
}

\section{Acknowledgements}

This work was supported by grants-in-aid from the Canadian Institutes of Health Research (CIHR) (MOP \#67228) and the Social Sciences \& Humanities Research Council (grant \#410-2004-0592). Drs Estabrooks and Lavis receive career support from the CIHR. Dr Wallin received post doctoral fellowship funding and Dr Scott received doctoral and post doctoral funding from CIHR and AHFMR during the conduct of this study. Iva Seto served as a research assistant, completed searches and did data cleaning under the direction of $\mathrm{CW}$. She was supported by the CIHR grant-in-aid MOP \#67228. Richard Thornley and Dagmara Chojecki assisted with final formatting and preparation of the manuscript. Glennis Zilm provided final editing services. They were supported by Dr Estabrooks' Canada Research Chair. Dr Olle Perrson, Sociology Institute, Umea University, Umea, Sweden was a consultant on the project and advised on methods, software training and use, and reviewed the final work for technical and methodological accuracy. His work was supported by the CIHR grant-in-aid MOP \#67228. The experts contacted for review of 'key players' document included (* denotes those who responded): UK: Huw Davies*, Joanne Rycroft-Malone*, Kieran Walshe; US: Lisa Bero, Robert Rich, Steve Shortell, Thomas Valente*; Canada: Jean Louis Denis, Karen Golden-Biddle*, Rejean Landry*, Jeremy Grimshaw*, Donna Ciliska*, Maureen Dobbins*. The authors thank the reviewers for thorough reviews that strengthened the manuscript considerably.

\section{References}

I. Nowotny H, Scott P, Gibbons M: Re-Thinking Science: Knowledge and the Public in an Age of Uncertainty Cambridge, MA: Polity Press; $200 \mathrm{I}$.

2. Stehr N: Modern society as knowledge societies. In Handbook of Social Theory Edited by: Ritzer G, Smart B. Thousand Oaks: Sage; 200I:494-508. 
3. Stehr N: Knowledge Societies Thousand Oaks: Sage; 1994.

4. Stehr N: A world made of knowledge. Society 200I, 39:89-92.

5. Gibbons M: Science's new social contract with society. Nature 1999, 402:C8I-84.

6. Allmark P: A classical view of the theory-practice gap in nursing. J Adv Nurs 1995, 22: 18-23.

7. Grimshaw J, Eccles M, Tetroe J: Implementing clinical guidelines: Current evidence and future implications. J Contin Educ Health Prof 2004, 24:S3I-37.

8. Serpa R: A systematic approach to technology transfer. Journal of Technology Transfer 1992, 17:16-19.

9. Ogburn WF: Cultural lag as theory. Sociology \& Social Research 1957, $41: 167-174$.

10. Rogers EM: Diffusion of Innovations 5th edition. New York: Free Press; 2003.

II. Baker GR, Norton PG, Flintoft V, Blais R, Brown A, Cox J, Etchells E, Ghali WA, Hebert P, Majumdar SR, O'Beirne M, Palacios-Derflingher L, Reid RJ, Sheps S, Tamblyn R: The Canadian Adverse Events Study: The incidence of adverse events among hospital patients in Canada. CMAJ 2004, 170:1678-1686.

12. Grol R, Grimshaw J: From best evidence to best practice: Effective implementation of change in patients' care. Lancet 2003, 362:1225-1230.

13. McGlynn EA, Steven MA, Adams J, Keesey J, Hicks J, DeCristofaro A, Kerr EA: The quality of health care delivered to adults in the United States. N Engl J Med 2003, 348:2635-2645.

14. Schuster MA, McGlynn EA, Brook RH: How good is the quality of health care in the United States? Milbank Q 2005, 83:843-895.

15. Estabrooks CA, Scott-Findlay S, Winther C: Knowledge utilization in nursing and the allied health sciences. In Multidisciplinary Perspectives on Evidence-Based Decision-Making in Health Care Edited by: Champagne F, Lemieux-Charles L. Toronto: University of Toronto; 2004:242-295.

16. Lang ES, Wyer PC, Haynes RB: Knowledge translation: Closing the evidence-to-practice gap. Ann Emerg Med 2007, 49:355-363.

17. Rich R: Knowledge creation, diffusion, and utilization: Perspectives from the founding editor of Knowledge. Knowledge: Creation, Diffusion, Utilization 1991, I 2:3 19-337.

18. Dunn WN, Holzner B: Knowledge in society: Anatomy of an emergent field. Knowledge in Society: The International Journal of Knowledge Transfer 1988, I:3-26.

19. Havelock RG, Havelock MC: Training for Change Agents: A Guide to the Design of Training Programs in Education and Other Fields Ann Arbor: Center for Research on Utilization of Scientific Knowledge, University of Michigan; 1973.

20. Weiss CH: Social Science Research in Decision Making New York: Columbia University Press; 1980.

21. Cottrill CA, Rogers AM, Mills T: Co-citation analysis of the scientific literature of innovation research traditions. Knowledge: Creation, Diffusion, Utilization 1989, I I : 18I-208.

22. White HD, Wellman B, Nazer N: Does citation reflect social structure? Longitudinal evidence from the "Globenet" interdisciplinary research group. Journal of the American Society for Information Science and Technology 2004, 55: I I I-126.

23. Rich RF: The pursuit of knowledge. Knowledge: Creation, Diffusion, Utilization 1979, I:6-30.

24. Tarde G: The Laws of Imitation New York: Holt; 1903.

25. Loomis ME: Knowledge utilization and research utilization in nursing. IMAGE: The Journal of Nursing Scholarship 1985, 17:35-39.

26. Shaperman J, Backer TE: The role of knowledge utilization in adopting innovations from academic medical centers. Hosp Health Serv Adm 1995, 40:40I-4I3.

27. Lindquist EA: What do decision models tell us about information use? Knowledge in Society 1988, I/2:86-III.

28. Lomas J: Connecting research and policy. Isuma 2000, I: $140-144$.

29. Nilsson K, Sunesson S: Strategy and tactics: Utilization of research in three policy sector contexts. The Journal of Applied Behavioral Science 1993, 29:366-383.

30. Sunesson S, Nilsson K: Explaining research utilization. Knowledge: Creation, Diffusion, Utilization 1988, 10:140-155.

31. Sunesson S, Nilsson K, Ericson B, Johansson B-M: Intervening factors in the utilization of social research. Knowledge in Society: The International Journal of Knowledge and Transfer 1989, 2:42-56.

32. Rich RF: Uses of social science information by federal bureaucrats: Knowledge for action versus knowledge for under- standing. In Using Social Research in Public Policy Making Edited by: Weiss CH. Lexington: DC Heath; 1977:199-2II.

33. Valente TW: Diffusion of innovations and policy decision-making. J Commun 1993, 43:30-45.

34. Weiss C: The many meanings of research utilization. Public Adm Rev 1979, 39:426-431.

35. Weiss $\mathrm{CH}$ : Knowledge creep and decision accretion. Knowledge: Creation, Diffusion, Utilization 1980, I:38I-404.

36. Glaser EM, Abelson HH, Garrison KN: Putting Knowledge to Use: Facilitating the Diffusion of Knowledge and the Implementation of Planned Change San Francisco: Jossey-Bass; 1983.

37. Backer TE: Knowledge utilization: The third wave. Knowledge: Creation, Diffusion, Utilization I99I, I 2:225-240.

38. Valente TW, Rogers EM: The origins and development of the diffusion of innovations paradigm as an example of scientific growth. Science Communication 1995, 16:242-273.

39. Beal GM, Dissanayake W, Konoshima S, (eds): Knowledge Generation, Exchange, and Utilization Boulder: Westview Press; 1986.

40. Crane D: Invisible Colleges: Diffusion of Knowledge in Scientific Communities Chicago: University of Chicago; 1972.

41. Rogers EM: Models of knowledge transfer: Critical perspectives. In Knowledge Generation, Exchange, and Utilization Edited by: Beal GM, Dissanayake W, Konoshima S. Boulder: Westview Press; 1986.

42. Rogers EM: Lessons for guidelines from the diffusion of innovations. Jt Comm J Qual Improv 1995, 2 1:324-328.

43. Lionberger HF: Adoption of New ideas and Practices Ames: lowa State University Press; 1960.

44. Seely B: Historical patterns in the scholarship of technology transfer. Comparative Technology Transfer \& Society 2003, 1:7-48.

45. Koerner ST: Technology transfer from Germany to Canada: A study in failure? Comparative Technology Transfer \& Society 2004, 2:99-124.

46. Evidence-Based Medicine Working Group: Evidence-based medicine: A new approach to teaching the practice of medicine. Journal of the American Medical Association 1992, 268:2420-2425.

47. Cochrane AL: Effectiveness and Efficiency: Random Reflections on Health Services London: Nuffield Provincial Hospitals Trust; 1972.

48. Moed HF: Citation Analysis in Research Evaluation Netherlands: Springer; 2005

49. White HD, McCain KW: Visualizing a discipline: An author cocitation analysis of information science, 1972-1995. J Am Soc Inf Sci 1998, 49:325-355.

50. White HD: Author co-citation analysis: Overview and defense. In Scholarly Communication and Bibliometrics Edited by: Borgman C. Newbury Park: Sage; 1990:84-106.

51. McCain KW: Mapping authors in intellectual space: A technical overview. J Am Soc Inf Sci 1990, 4 I:433-443.

52. McCain KW, Verner JM, Hislop GW, Evanco W, Cole V: The use of bibliometric and knowledge elicitation techniques to map a knowledge domain: Software engineering in the 1990s. Scientometrics 2005, 65:13I-I 44.

53. Small HG: Cited documents as concept symbols. Social Studies of Science 1978, 8:327-340.

54. Zuckerman $\mathrm{H}$ : Citation analysis and the complex problem of intellectual influence. Scientometrics 1987, I 2:329-338.

55. Merton RK: The Sociology of Science: Theoretical and Empirical Investigations Chicago: University of Chicago Press; 1973.

56. Latour B: Science in Action: How to Follow Scientists and Engineers through Society Cambridge: Harvard University Press; 1987.

57. Callon M: Elements of a sociology of translation: Domestication of the scallops and the fishermen of St. Brieuc Bay. In Power, Action, and Belief: A New Sociology of Knowledge? Edited by: Law J. London: Rutledge; 1986:196-233.

58. Merton RK: The sociology of science: An episodic memoir. In The Sociology of Science in Europe Edited by: Merton RK, Gaston J. Carbondale: Southern Illinois University Press; 1977:3-141.

59. Merton RK: The Matthew Effect in science II: Cumulative advantage and the symbolism of intellectual property. In On Social Structure and Science Edited by: Merton RK. Chicago: University of Chicago Press; 1996:318-336.

60. Small HG: On the shoulders of Robert Merton: Towards a normative theory of citation. Scientometrics 2004, 60:71-79.

61. White HD, Griffith BC: Author cocitation: A literature measure of intellectual structure. J Am Soc Inf Sci I98I, 32:163-17I. 
62. Lievrouw LA: The invisible college reconsidered: Bibliometrics and the development of scientific communication theory. Communication Research 1989, 16:615-628.

63. Gmür M: Co-citation analysis and the search for invisible colleges: A methodological evaluation. Scientometrics 2003, 57:27-57.

64. de Solla Price DJ: Little Science, Big Scienceand Beyond New York: Columbia University Press; 1963.

65. Zuccala A: Modeling the invisible college. Journal of the American Society for Information Science and Technology 2006, 57:152-168.

66. Walker G, Janes J: Online Retrieval: A Dialogue of Theory and Practice 2nd edition. Englewood, Colorado: Libraries Unlimited; 1999.

67. Okubo Y: Bibliometric Indicators and Analysis of Research Systems: Methods and Examples Paris: OECD; 1997.

68. Bibliometrics as a Research Field: A Course on Theory and Application of Bibliometric Indicators: Course Handouts [http://www.norslis.net/2004/Bib Module KUL.pdf]

69. Leydesdorff L: Similarity measures, author cocitation analysis, and information theory. Journal of the American Society for Information Science and Technology 2005, 56:769-772.

70. Hamers L, Hemerick Y, Herweyers G, Janssen M, Keters H, Rousseau $R$, Vanhoutte A: Similarity measures in scientometric research: The Jaccard index versus Salton's cosine formula. Information Processing and Management 1989, 25:315-318.

71. Persson O: A tribute to Eugene Garfield - discovering the intellectual base of his discipline. Curr Sci 2000, 79:590-59l.

72. White HD, McCain KW: Visualization of literatures. Annual Review of Information Science and Technology 1997:99-168.

73. Collins HM: The place of the 'core-set' in modern science: Social contingency with methodological propriety in science. History of Science 1981, 19:6-19.

74. Collins HM: Changing Order: Replication and Induction in Scientific Practice 2nd edition. Chicago: University of Chicago Press; 1992.

75. Small HG, Crane D: Specialties and disciplines in science and social science: An examination of their structure using citation indexes. Scientometrics 1979, 1:445-46।.

76. Rogers EM: Diffusion of Innovations Ist edition. New York: The Free Press; 1962.

77. Rogers EM, Shoemaker FF: Communication of Innovations: A Cross Cultural Approach New York: Free Press; 1971.

78. Katz E: Communication research and the image of society: Convergence of two traditions. American Journal of Sociology 1960, 65:435-504.

79. Katz $E$, Levin ML, Hamilton H: Traditions of research on the diffusion of innovation. Am Sociol Rev 1963, 28:237-252.

80. Coleman J, Katz E, Menzel H: The diffusion of an innovation among physicians. Sociometry 1957, 20:253-270.

81. Coleman JS, Katz E, Menzel H: Medical Innovation: A Diffusion Study Indianapolis: Bobbs-Merrill; 1966.

82. Mansfield $E$ : The speed of response of firms to new techniques. Quarterly Journal of Economics 1963, 77:290-3II.

83. Mansfield E: Intrafirm rates of diffusion of an innovation. The Review of Economics and Statistics 1963, 45:348-359.

84. Mansfield E: Size of firm, market structure, and innovation. The Journal of Political Economy 1963, 71:556-576.

85. Griliches Z: Hybrid corn: An exploration in the economics of technological change. Econometrica 1957, 25:501-522.

86. Allen TJ, Cohen SI: Information flow in research and development laboratories. Adm Sci Q 1969, 14:12-19.

87. Sarter B: Some critical philosophical issues in the science of unitary human beings. Nurs Sci $Q$ 1989, 2:74-78.

88. Hägerstrand T: The Propogation of Innovation Waves Lund, Sweden: University of Lund; 1952.

89. Hägerstrand T: Innovation Diffusion as a Spatial Process Chicago: Chicago University Press; 1967.

90. Brown LA: Diffusion of Processes and Location: A Conceptual Framework and Bibliography Philadelphia: Regional Science Research Institute; 1968.

91. Hägerstrand T: Aspects of the spatial structure of social communication and the diffusion of information. Papers in Regional Science 1966, 16:27-42.

92. Hägerstrand T: A Monte-Carlo approach to diffusion. Archives Européennes de Sociologie 1965, 6:43-67.

93. Gouldner AW: Cosmopolitans and locals: Toward an analysis of latent social roles - I. Adm Sci Q 1957, 2:444-480.
94. Duncan JW: Transferring management theory to practice. Acad Manage J 1974, 17:724-738.

95. Churchman CW: Managerial acceptance of scientific recommendations. Calif Manage Rev 1964, 7:3I-38.

96. Churchman $\mathrm{CW}$ : The researcher and the manager: A dialectic of implementation (with A.H. Schainblatt). Management Science 1965, II:B69-B87.

97. Salton G, et al:: Information Storage and Retrieval (Reports ISR-7, ISR-8, and ISR-9) Cambridge: National Science Foundation, Harvard Computation Lab; 1964.

98. Salton G: Information dissemination and automatic information systems. Proceedings of the IEEE 1966, 54:1663-1678.

99. Caplan NS, Morrison AS, Stambaugh RJ: The Use of Social Science Knowledge in Public Policy Decisions at the National Level: A Report to Respondents Ann Arbor: Center for Research on Utilization of Scientific Knowledge, University of Michigan; 1975.

100. Havelock RG: Planning for Innovation through Dissemination and Utilization of Knowledge Ann Arbor: Center for Research on Utilization of Scientific Knowledge, University of Michigan; 1969.

10I. Havelock RG: Planning for Innovation through Dissemination and Utilization of Knowledge Ann Arbor: Center for Research on Utilization of Scientific Knowledge, University of Michigan; 1971.

102. Yin RK: Changing Urban Bureaucracies: How New Practices Become Routinized Santa Monica: Rand Corp; 1978.

103. Yin RK, Gwaltney MK: Knowledge utilization as a networking process. Science Communication I98I, 2:555-580.

104. Vall M Van de: Utilization and methodology of applied social research: Four complementary models. J Appl Behav Sci 1975, I I:I4-38.

105. Vall M Van de, Bolas C, Kang TS: Applied social research in industrial organizations: An evaluation of functions, theory, and methods. J Appl Behav Sci 1976, I 2:158-177.

106. Mitroff II: The Subjective Side of Science: A Philosophical Inquiry into the Psychology of the Apollo Moon Scientists New York: Elsevier; 1974.

107. Merton RK: Social Theory and Social Structure Ist edition. New York: Free Press; 1957.

108. Merton RK: Social Theory and Social Structure Enlarged edition. Glencoe: Free Press; 1968.

109. Merton RK, Fiske M, Kendall PL: The Focused Interview: A Manual of Problems and Procedures New York: Free Press; 1990.

1 10. Mansfield $\mathrm{E}$ : Technical change and the rate of imitation. Econometrica 196I, 29:74I-766.

III. Mansfield E: Industrial Research and Technological Innovation: An Econometric Analysis New York: W.W. Norton; 1968.

1 12. Mansfield E: The Economics of Technological Change Ist edition. New York: W. W. Norton; 1968.

113. Allen TJ: Managing the Flow of Technology: Technology Transfer and the Dissemination of Technological Information within the $R$ \& D Organization Cambridge: MIT Press; 1977.

II4. Cooney S, Allen TJ: The technological gatekeeper and policies for national and international transfer of information. $R \& D$ Management 1974, 5:29-33.

I I5. Fitzgerald L, Ferlie E, Hawkins C: Innovation in healthcare: How does credible evidence influence professionals? Health and Social Care in the Community 2003, I I:219-228.

116. Bulte C Van den, Lilien GL: Medical innovation revisited: Social contagion versus marketing effort. American Journal of Sociology 200I, 106: 1409-1436.

II7. West E, Barron DN, Dowsett J, Newton JN: Hierarchies and cliques in the social networks of health care professionals: implications for the design of dissemination strategies. Soc Sci Med 1999, 48:633-646.

1 18. Sackett DL: Clinical epidemiology: What, who, and whither. J Clin Epidemiol 2002, 55: I I61-II66.

I19. Guyatt GH, Haynes RB, Jaeschke RZ, Cook DJ, Green L, Naylor CD, Wilson MC, Richardson WS: Users' guides to the medical literature: Xxv. Evidence-based medicine: Principles for applying the users' guides to patient care. JAMA 2000, 284:1290-1296.

120. Guyatt GH, Meade MO, Jaeschke RZ, Cook DJ, Haynes RB: Practitioners of evidence based care: Not all clinicians need to appraise evidence from scratch but all need some skills. $\mathrm{Br}$ Med J 2000, 320:954-955.

I2I. Haynes RB: What kind of evidence is it that evidence-based medicine advocates want health care providers and consumers to pay attention to. BMC Health Serv Res 2002, 2:3. 
122. Grol R: Improving the quality of medical care: building bridges among professional pride, payer profit, and patient satisfaction. JAMA 200I, 286:2578-2585.

123. Nowotny H, Scott P, Gibbons M: Mode 2 revisited: The new production of knowledge. Minerva 2003, 4I: I79-194.

124. Orszag PR, Ellis P: Addressing rising health care costs - a view from the Congressional Budget Office. N Engl J Med 2007, 357: $1885-1887$.

125. Hart WB: Everett M. Rogers: His role in intercultural communication study. International Journal of Intercultural Relations 2005, 29:491-495.

126. Haider M, Kreps GL: Forty years of diffusion of innovations: Utility and value in public health. Journal of Health Communication 2004, 9:3-II.

127. Rogers EM: Diffusion of Innovations 3rd edition. New York: The Free Press; 1983.

128. Rogers E: Diffusion of Innovations 4th edition. New York: The Free Press; 1995.

129. Zaltman G, Duncan R, Holbek J: Innovations and Organizations Toronto: John Wiley \& Sons; 1973.

130. Zaltman G: Strategies for Planned Change New York: Wiley; 1977.

I 3 I. Weiss CH, (ed): Using Social Research in Public Policy Making Lexington: Lexington Books; 1977.

132. Gandhi AG, Murphy-Graham E, Petrosino A, Chrismer SS, Weiss CH: The devil is in the details: Examining the evidence for "proven" school-based drug abuse prevention programs. Eval Rev 2007, 3 I:43-74.

133. Mark M, Weiss $\mathrm{CH}$ : The oral history of evaluation, part 4: The professional evolution of Carol H Weiss. American Journal of Evaluation 2006, 27:475-484.

134. Kothari A, Birch S, Charles C: "Interaction" and research utilisation in health policies and programs: Does it work? Health Policy 2005, 71 : II 7-125.

135. Weiss $\mathrm{CH}$ : Have we learned anything new about the use of evaluation. American Journal of Evaluation 1998, 19:21-33.

136. Allen TJ, Hyman DB, Pinckney DL: Transferring technology to the small manufacturing firm: A study of technology transfer in three countries. Research Policy 1983, I2:199-2 II.

137. Blackman AW: The market dynamics of technological substitutions. Technological Forecasting and Social Change 1974, 6:41-63.

138. Mahajan V, Peterson RA: Models for Innovation Diffusion Beverly Hills: Sage; 1985.

139. Mahajan V, Peterson RA: Integrating time and space in technological substitution models. Technological Forecasting and Social Change 1979, |4:23|-24I.

140. Kuhn T: The Structure of Scientific Communities Chicago: University of Chicago Press; 1962.

141. Ryan B, Gross NC: The diffusion of hybrid corn seed in two lowa communities. Rural Sociology 1943, 8:15-24.

142. Rogers EM: A prospective and retrospective look at the diffusion model. Journal of Health Communication 2004, 9: I3-19.

143. Backer TE: Forum: The life and work of Everett Rogers Some personal reflections. 2005, 10:285-288.

144. Knorr Cetina K: Epistemic Cultures Cambridge: Harvard University Press; 1999.

145. Backer TE, Dearing J, Singhal A, Valente T: Writing with Ev Words to transform science into action. Journal of Health Communication 2005, 10:289-302.

146. Rogers EM, Medina UE, Rivera MA, Wiley CJ: Complex adaptive systems and the diffusion of innovations. The Innovation Journal 2005, 10:article 29.

147. Farley G, Geison GL: Science politics and spontaneous generation in nineteenth-century France: The Pasteur-Pouchet debate. Bull Hist Med 1974, 48: 161-198.

148. Shapin S: The Social History of Truth Chicago: Chicago University Press; 1996.

149. Bridging the "Know-do" Gap in Global Health [http:// www.who.int/kms/en/]

150. Cronin B: Bibliometrics and beyond: Some thoughts on webbased citation analysis. Journal of Information Science 200 I, 27: I-7.

15I. Beall J, Kafadar K: Measuring typographical errors' impact on retrieval in bibliographic databases. Cataloging \& Classification Quarterly 2007, 44:197-2II.

152. Gibbons M, Limoges C, Nowotny H, Schwartzman S, Scott P: The New Production of Knowledge London: Sage; 1994.
Publish with Bio Med Central and every scientist can read your work free of charge

"BioMed Central will be the most significant development for disseminating the results of biomedical research in our lifetime. "

Sir Paul Nurse, Cancer Research UK

Your research papers will be:

- available free of charge to the entire biomedical community

- peer reviewed and published immediately upon acceptance

- cited in PubMed and archived on PubMed Central

- yours - you keep the copyright
BioMedcentral 